\title{
THE LAHORE JOURNAL OF
}

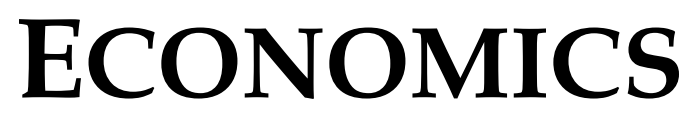

Lahore School of Economics

Imtiaz Ahmad and Zafar Mahmood

Inventory, Marketing and

Markups of Exporters: The

Case of Spinning, Weaving and Finishing Textile Sector of Pakistan

Matthew McCartney

The China-Pakistan

Economic Corridor (CPEC):

Considering Contemporary

Pakistan through Old-

Fashioned Economics and

Historical Case Studies

John Francis Diaz, Peh Ying

Qian and Genevieve Liao Tan

Variance Persistence in the

Greater China Region: A

Multivariate GARCH

Approach
Jamshed Y. Uppal and Inayat

U. Mangla

Role of Financial Services in

Economic Growth: Policy

Implications for Pakistan
Natasha Moeen

Human and Social Capital

Complementarities in the

Presence of Credit Market

Imperfections

Volume 23, No.2

July-Dec, 2018

Syed Kumail Abbas Rizvi, Bushra Naqvi and Fatima Tanveer

Is Pakistan Ready to Embrace Fintech Innovation? 



\section{THE LAHORE JOURNAL OF ECONOMICS}

Editors

Dr. Azam Chaudhry, Editor

Dr. Theresa Thompson Chaudhry, Editor

Ms. Nina Gera, Associate Editor

Ms. Ayesha Khanum, Assistant Editor

\section{Editorial Advisory Board}

Ranil Abayasekara

University of Peradeniya

Sirimal Abeyratne

University of Colombo

Julio Aguirre

Universidad del Pacífico

Rashid Amjad

Lahore School of Economics

Mathew Andrews

Harvard University

Mohammad Arzaghi

American University of Sharjah

David Atkin

MIT

Shahid Amjad Chaudhry

Lahore School of Economics

Matthias Cinyabuguma

World Bank

Sean Corcoran

New York University

Giovanna d'Adda

Politecnico di Milano, University of

Birmingham

Phillip Garner

Dixie State University

Javier Arze del Granado

International Monetary Fund

Ramani Gunatilaka

University of Colombo

Aamir Rafique Hashmi

National University of Singapore

S. Ajaz Hussain

University of Toronto

Kazi Iqbal

Bangladesh Institute of Development Studies

Sanjay Jain

University of Cambridge

Michal Jerzmanowski

Clemson University

Ahmed Kamaly

The American University in Cairo
Ahmed M. Khalid

Bond University

Amir Jahan Khan

Coventry University

Saleem Khan

Bloomsburg University

Shahrukh Rafi Khan

Mount Holyoke College

Amit Khandelwal

Columbia University

Rocco Macchiavello

London School of Economics

Minhaj Mahmud

BRAC University

Adeel Malik

University of Oxford

Inayat Ullah Mangla

Western Michigan University

Ghazala Mansuri

World Bank

Matthew McCartney

Nawazish Mirza

SP Jain School of Global Management

Ahmed Mushfiq Mobarak

Yale University

John Morrow

University of Essex

Kamal Munir

University of Cambridge

Khalid Nadvi

University of Manchester

Zareen Naqvi

British Columbia Institute of

Technology

Ashish Narain

World Bank

Robert Neild

University of Cambridge

Roshan Perera

Central Bank of Sri Lanka
University of Oxford
Baoyun Qiao

Central University of Finance and

Economics, China

Simon Quinn

University of Oxford

Atonu Rabbani

University of Dhaka

Dhushyanth Raju

World Bank

Rajah Rasiah

University of Malaya

Syed Kumail Abbas Rizvi

Lahore School of Economics

Anwar Shah

Southwestern University of Finance and Economics, China

Sohaib Shahid

International Monetary Fund

Chad Syverson

University of Chicago

Gwendolyn A. Tedeschi

Manhattan College

Kensuke Teshima

Instituto Tecnológico Autónomo de México

Jamshed Y. Uppal

Catholic University of America

Eric Verhoogen

Columbia University

Kate Vyborny

Duke University

Waqar Ahmed Wadho

Lahore School of Economics

Jan Weiss

Jönköping International Business School

Christopher Woodruff

University of Oxford

Bushra Yasmin

Fatima Jinnah Women University

Sohail Zafar

Lahore School of Economics
Editorial Staff:

Telefax:

E-mail:

Publisher:
Tele. No: 0092 - 42 - 36560969

0092 - 42 - 36560905

nina@lahoreschool.edu.pk, nina_lse@yahoo.com

Lahore School of Economics, Lahore, Pakistan.

Correspondence relating to subscriptions and changes of address should be sent to The Lahore Journal of Economics, 104 -C-2, Gulberg-III, Lahore - 54660 - Pakistan.

Instructions to authors can be found at the end of this issue. No responsibility for the views expressed by authors and reviewers in The Lahore Journal of Economics is assumed by the Editors, the Associate Editor and the Publisher. 



\section{THE LAHORE JOURNAL OF ECONOMICS}

\section{Contents $\quad$ Vol. 23, No.2, 2018}

Inventory, Marketing and Markups of Exporters: The Case of Spinning, Weaving and Finishing Textile Sector of Pakistan Imtiaz Ahmad and Zafar Mahmood

The China-Pakistan Economic Corridor (CPEC): Considering Contemporary Pakistan through Old-Fashioned Economics and Historical Case Studies

Matthew McCartney

Variance Persistence in the Greater China Region: A Multivariate GARCH Approach John Francis Diaz, Peh Ying Qian and Genevieve Liao Tan

Role of Financial Services in Economic Growth: Policy Implications for Pakistan Jamshed Y. Uppal and Inayat U. Mangla

Human and Social Capital Complementarities in the Presence of Credit Market Imperfections

Natasha Moeen

Is Pakistan Ready to Embrace Fintech Innovation?

Syed Kumail Abbas Rizvi, Bushra Naqvi and Fatima Tanveer 



\section{Notes for Authors}

1. Manuscripts will be accepted for consideration on the understanding that they are original contributions to the existing knowledge in the fields of Economics, Banking, Current Affairs, Finance, Political Economy, Sociology, and Economic History.

2. Electronic copies of research articles, research notes, and book reviews - in English only - should be submitted as an email attachment to: nina@lahoreschool.edu.pk and nina_lse@yahoo.com. Upon receipt, a confirmation email will be sent to the corresponding author containing a serial number identifying the article.

3. The first page of the manuscript should have the title of the paper, the names(s) of author(s), and a footnote giving the current affiliation of the author(s) and any acknowledgments

4. Articles submitted to the Lahore Journal of Economics must also include: (a) a brief abstract of about 100 words that summarizes the contents, (b) keywords and (c) Journal of Economic Literature (JEL) Classification Codes.

5. The Lahore Journal of Economics will publish empirical papers only if the data used in the analyses are clearly and precisely documented and are readily available to the journal reviewers for purposes of replication. At the time of submission of papers that have empirical work, authors must provide to the Lahore Journal of Economics, the data in Microsoft EXCEL format required for the replication of results.

6. Detailed derivations of any main mathematical results reported in the text should be submitted separately along with the articles.

7. Each manuscript should be typed and should carry a margin of an inch and a half on the left-hand side and an inch on the right hand side of the typed page.

8. The graphic format for each mathematical formula, diagram, figure or chart should be in text mode for further editing.

9. Tables for the main text and each of its appendices should be numbered sequentially and separately. The title of each table should clearly describe the contents. The source of the table should be given in a footnote immediately below the line at the bottom of the table.

10. Footnotes should be numbered sequentially. 
11. All references used in the text should be listed in alphabetical order of the authors' surnames at the end of the text. References in the text should include the name(s) of author(s) with the year of publication in parentheses, and all references should conform to the style of the Journal. Further information on questions of style may be obtained from the Associate Editor, The Lahore Journal of Economics, Lahore Pakistan.

12. Book Reviews should give a description of the contents and a critical evaluation of the book. It should not exceed 5 or 6 typewritten pages.

13. Each author will receive two complimentary copies of The Lahore Journal of Economics. 


\title{
THE LAHORE JOURNAL \\ OF
}

\author{
ECONOMICS
}

\section{Lahore School of Economics}

\author{
104-C-2, GULBERG III LAHORE, PAKISTAN. TEL: 35870704
}

\section{SUBSCRIPTION FOR PUBLICATIONS}

1. Kindly enter a subscription for the following publication of the Lahore School of Economics:
Publication Yearly subscription Yearly subscription Period Total (within Pakistan) (outside Pakistan) (No. of years) Payment

1. The Lahore Journal Rs. $600.00 \quad$ US $\$ 50$

of Economics

2. The subscription is to be in the following name and address:

Name:

Address:

Telephone:

3. A crossed cheque/demand draft for the sum of Pakistan Rupees/US \$___ is enclosed made out in the name of The Lahore School of Economics to cover the above subscription.

4. Please address your order to: Nina Gera, Publications, Lahore School of Economics, 104-C-2, Gulberg III, Lahore 54660, Pakistan.

\section{Signature:}

Name:

Date: 




\section{The Lahore School of Economics}

The Lahore School of Economics (established 1993) is one of Pakistan's leading centres of learning for teaching and research in economics, finance and business administration. The Lahore School of Economics' objectives include: (i) The training of young Pakistanis as professional economists, finance managers, accountants, financial analysts, bankers and business executives, and (ii) Undertaking research in economics, management, finance and banking to further deepen understanding of major economic facts, issues and policies.

The Lahore School was granted a Charter in January, 1997 by an Act of the Provincial Assembly of the Punjab: The Lahore School of Economics Act 1997 (Act II of 1997). The Charter vests the powers of an independent degree granting institution to The Lahore School.

The Lahore School has both undergraduate and graduate programs in economics, business information systems and finance. Its postgraduate program leading to the MPhil and PhD degree is administered through the Lahore School's Centre for Research in Economics and Business (CREB). The student body and faculty comprise both national and expatriate Pakistanis and The Lahore School encourages expatriate Pakistanis to join as students or as faculty.

The Lahore School's publication program comprises The Lahore Journal of Economics, The Lahore Journal of Business, The Lahore Journal of Policy Studies, a Working Paper Series, a Seminar Paper Series and a Text Book Series. The Program encourages both in-house and external contributors.

For further information, please call (Pakistan 92-42-) 35870704 or 36560969 or visit the Web page: www.lahoreschoolofeconomics.edu.pk 